\title{
Jogpolitika
}

\author{
Gajduschek GYÖRgY-FeKETE BALÁZs*
}

\section{A jogismeretet befolyásoló társadalmi tényezők elemzése}

\author{
jogszociológia - empirikus kutatás - jogismeret - jogi kultúra
}

A Pro Futuro előző számában megjelent írásunkban bemutattuk azt a munkát, amellyel Kulcsár Kálmán jogismereti kutatását ${ }^{1}$ kívántuk rekonstruálni és részben megismételni. Ismertettük azokat a módszereket, amelyekkel az összevetés nehézségeit kezeltük, végül vázoltuk a kutatás legáltalánosabb eredményét, amely a jogismeret változására mutatott rá, az egyes konkrét kérdések, az egyes jogterületek általánosabb szintjén, és a teljes jogismeret szintjén egyaránt. Ebben a tanulmányban kiindulásként azt elemezzük különféle módszerekkel, hogy milyen tényezők hatnak, illetve hatottak a jogismeretre, majd visszatérünk az alapkérdéshez, és azt vizsgáljuk, hogy miként értelmezhetők adataink a magyar társadalom teljes jogismeretét tekintve.

Az alábbiakban három pontba szedve azt tekintjük át, hogy a jogismeretre ható tényezök miként "müködtek” 1965-ben, és hogy ehhez viszonyitva, hogyan értelmezhetö ugyanezen tényezők hatása 2013-ban. Kiindulópontunkat tehát ismét Kulcsár elemzése jelenti, amely - értelmezésünk szerint - a következő három általános tényező-csoport hatását vizsgálta:

1. szociodemográfiai tényezök (amelyek közül Kulcsár öt tényezőt vizsgált részletesen);

2. általános közéleti tájékozottságot befolyásoló tényezők;

3. kapcsolatba kerülés a jogrendszerrel.

* Dr. Gajduschek György egyetemi tanár, Budapesti Corvinus Egyetem; osztályvezető, tudományos fömunkatárs, MTA Társadalomtudományi Kutatóközpont Jogtudományi Intézet, Budapest, gajduschek.gyorgy@ tk.mta.hu. Dr. Fekete Balázs egyetemi adjunktus, Eötvös Loránd Tudományegyetem Állam- és Jogtudományi Kar; tudományos munkatárs, MTA Társadalomtudományi Kutatóközpont Jogtudományi Intézet, Budapest, fekete.balazs@tk.mta.hu.

Jelen dolgozat az OTKA 105552, „A magyar lakosság jogtudata - elméleti és empirikus elemzés” címü projekt keretében készült. A mögöttes adatfelvétel költségeit is ez a kutatás biztosította.

1 KuLCSÁr Kálmán: A jogismeret vizsgálata. MTA JTI, Budapest, 1967. 


\section{A szociodemográfiai tényezők hatása a jogismeretre}

Kulcsár elemzésében öt szocio-demográfiai tényezőt használ fel: nem, kor, iskolai végzettség, foglalkozási csoport és a lakóhely településtípusa. A kifejezetten demográfiai, ha úgy tetszik biológiai tényezőkhöz (kor, nem) is társadalmi jellemzők társulnak.

Különösen igaz ez a nemi szerepek és a kor vonatkozásában. A hatvanas években a nők nagyon jelentős része háztartásbeli volt, ami kihatott tájékozottságukra is (ebben az időben a tv jórészt ismeretlen volt, és számos háztartásban még a villany se volt bevezetve). ${ }^{2}$ Hasonló volt a helyzet az idősebbek körében. Nem szabad azonban szem elöl téveszteni, hogy ezek a csoportok nem jelennek meg a kutatásban, hiszen csak az aktív dolgozókat kérdezték. (A teljes lakossági jogismeret tehát nyilván alacsonyabb szintủ lett volna, mint ami a felmérés adataiból előállt.) $A z$ azonban tudható, és az adatokból is érzékelhető, hogy a nők emancipációja kezdeti szakaszban járt, ami az iskolai végzettség adataiból is látható. $E$ tekintetben óriási változás ment végbe az elmúlt fél évszázadban.

Szociális jellemzőként Kulcsár kutatása a lakóhelyet, az iskolai végzettséget és a foglalkoztatási csoportba tartozást tartalmazza. Ezeket ma státusváltozóknak neveznénk. ${ }^{3} \mathrm{~A}$ településtípus szerinti felosztást a már bemutatott adatfelvételi korlátok nagyban befolyásolták, bár a táblázatokban használt „Budapest-város-község” kategorizálás ezt elfedi. Az iskolai végzettség kapcsán hét kategóriát vettek fel, amit 2013-ban lényegében mi is követtünk. Szembetűnő, bár nem meglepő változás az iskolába nem jártak eltünése, a nyolc osztályt vagy annál kevesebbet végzettek arányának jelentős csökkenése (65\%-ról, 20\%-ra), míg a felsőfokú végzettségűek az 1965-ös felülreprezentáltsága miatt ez az arány alig nőtt. Mindezt, de különösen az iskolai végzettség mutatójának igen nagy mértékủ javulását az adatok értelmezése során figyelembe kell venni. (Ez ugyanis a jogrendszertől, a jogi tájékoztatástól teljesen független tényező.) A foglalkoztatási csoportra vonatkozóan, ebben az időszakban megszokott módon mezőgazdasági fizikai - fizikai - és szellemi dolgozók közt (lásd még: parasztság, munkásság, értelmiség) tesz különbséget a kutatás, és az összehasonlítás céljából ezt mi is követtük.

Az alábbi elemzésben elsőként a jogismeret korábban már bemutatott indexadatait vizsgáljuk, aszerint, hogy azok milyen összefüggést mutatnak a szociodemográfiai változókkal. Ezután az 1965-ös és a 2013-as adatok táblázataira vonatkozó khi-négyzet-értékeket vizsgáljuk röviden. Ezeknek a tényezőknek a hatását az utolsó fejezetben korrelációs és regressziós elemzésnek is alávetjük.

2 A Kádár-kori női szerepekröl lásd TóтH Eszter Zsófia: Kádár leányai. Nők a szocialista időszakban. Nyitott Könyvmühely, Budapest, 2010.

3 Lásd KoLosı Tamás: Tagolt társadalom. Struktúra, rétegződés, egyenlőtlenség Magyarországon. Gondolat, Budapest, 1987. 


\subsection{Ismeretindexek összefüggése az öt szociodemográfiai változóval}

Milyen típusú összefüggés ismerhetö fel a jogismeretre számított indexváltozók és a szocio-demográfiai változók között? Ehhez kiindulópontunk az 1. táblázat, amely a teljes jogismereti indikátorokat mutatja be részletesen a szociodemográfiai adatok szerinti bontásban. A 2013-ra vonatkozó adatok esetében a Kulcsár mintájához torzított adatokra nézve (ezek tehát a 2013f_k fejlécủ oszlop adatai) közöljük az ANOVA-elemzés alapján, hogy az adott szempont szerint az egyes csoportok jogismeretében fellelhető eltérések szignifikánsak-e. ${ }^{4} \mathrm{Az}$ így számított $\mathrm{F}$ érték és a szignifikancia jelenik meg a bal szélső oszlopban, az adott tényező megnevezése alatt. Ez az adat tehát a jogismeret és az adott változó összefüggésének szorosságára utal 2013-ban. Egyfajta hüvelykujjszabály, hogy ha 1965-ben a csoportátlagok közötti eltérés nagyobb volt, akkor valószínüleg erösebb lehetett a statisztikai összefüggés is (bár az ANOVA a szórás és nem az átlagok értékeit elemzi).

\section{1. táblázat}

Teljes jogismeret-indikátorok átlagai szociodemográfiai bontásban (a két jobb oldali oszlopban szerepelnek az ANOVA-értékek)

\begin{tabular}{|c|c|c|c|c|c|c|c|}
\hline & & \multicolumn{3}{|c|}{ Alapsokaságból számított } & \multicolumn{3}{|c|}{ Táblázatokból számított } \\
\hline \multicolumn{2}{|c|}{ Megoszlás típusa } & $1965 \mathrm{fa}$ & $2013 \mathrm{f} \_t$ & 2013 f_k & 1965 ta & 2013 sz_t & 2013 sz_k \\
\hline \multirow{3}{*}{$\begin{array}{l}\text { A kérdezett } \\
\text { neme } \\
F=0,02 \\
0,897\end{array}$} & férfi & 0,57 & 0,69 & 0,70 & 0,63 & 0,68 & 0,69 \\
\hline & nő & 0,53 & 0,67 & 0,70 & 0,56 & 0,66 & 0,69 \\
\hline & Összesen & 0,55 & 0,68 & 0,70 & 0,60 & 0,67 & 0,69 \\
\hline \multirow{6}{*}{$\begin{array}{l}\text { A kérdezett } \\
\text { korcsoportja } \\
F=5,62 \\
0,000\end{array}$} & $18-29$ & 0,57 & 0,67 & 0,67 & 0,61 & 0,65 & 0,65 \\
\hline & 30-39 & 0,55 & 0,70 & 0,70 & 0,61 & 0,69 & 0,70 \\
\hline & $40-49$ & 0,58 & 0,71 & 0,72 & 0,61 & 0,70 & 0,72 \\
\hline & $50-59$ & 0,56 & 0,70 & 0,68 & 0,57 & 0,70 & 0,69 \\
\hline & 60 éven felül & 0,52 & 0,66 & 0,72 & 0,54 & 0,64 & 0,71 \\
\hline & Összesen & 0,55 & 0,68 & 0,70 & 0,60 & 0,67 & 0,69 \\
\hline \multirow{4}{*}{  } & szellemi dolgozó & 0,61 & 0,73 & 0,74 & 0,74 & 0,72 & 0,74 \\
\hline & fizikai dolgozó & 0,53 & 0,67 & 0,67 & 0,58 & 0,66 & 0,67 \\
\hline & mezőgazdasági fizikai & 0,50 & 0,61 & 0,66 & 0,46 & 0,61 & 0,65 \\
\hline & Összesen & 0,55 & 0,68 & 0,70 & 0,60 & 0,67 & 0,69 \\
\hline
\end{tabular}

4 A tanulmányban alkalmazott matematikai statisztikai fogalmak és eljárások mibenlétét a lap előző számában megjelent cikkünkben részletesen bemutattuk. A szignifikancia kapcsán itt arra emlékeztetünk, hogy annak értéke 0-1 között mozog, s minél alacsonyabb, annál biztosabbak lehetünk az adott összefüggés fennállásában. 


\begin{tabular}{|c|c|c|c|c|c|c|c|}
\hline & & \multicolumn{3}{|c|}{ Alapsokaságból számított } & \multicolumn{3}{|c|}{ Táblázatokból számított } \\
\hline \multicolumn{2}{|c|}{ Megoszlás típusa } & $1965 \mathrm{fa}$ & 2013 f_t & 2013 f_k & 1965 ta & 2013 sz_t & 2013 sz_k \\
\hline \multirow{8}{*}{$\begin{array}{l}\text { Iskolai } \\
\text { végzettség } \\
F=13,44 \\
0,000\end{array}$} & nem járt iskolába & ** & ** & ** & 0,36 & ** & ** \\
\hline & általános $1-7$. osztály & $* *$ & 0,56 & 0,63 & 0,47 & 0,53 & 0,59 \\
\hline & általános iskola & ** & 0,60 & 0,64 & 0,58 & 0,60 & 0,64 \\
\hline & $\begin{array}{l}\text { középiskola, de } \\
\text { érettségi nincs }\end{array}$ & ** & 0,68 & 0,67 & 0,69 & 0,66 & 0,67 \\
\hline & érettségi & ** & 0,71 & 0,71 & 0,73 & 0,70 & 0,70 \\
\hline & $\begin{array}{l}\text { egyetemre (föiskolára) } \\
\text { járt, de diploma nincs }\end{array}$ & ** & ** & ** & 0,73 & ** & ** \\
\hline & diploma & ** & 0,75 & 0,75 & 0,77 & 0,74 & 0,75 \\
\hline & Összesen & ** & 0,68 & 0,70 & 0,60 & 0,67 & 0,69 \\
\hline \multirow{4}{*}{$\begin{array}{l}\begin{array}{l}\text { Település- } \\
\text { típus- } \\
\text { kategóriák } \\
F=2,01 \\
0,134\end{array}\end{array}$} & Budapest & 0,55 & 0,70 & 0,71 & 0,63 & 0,70 & 0,71 \\
\hline & város* & 0,56 & 0,67 & 0,69 & 0,63 & 0,67 & 0,68 \\
\hline & falu & 0,52 & 0,68 & 0,69 & 0,48 & 0,66 & 0,67 \\
\hline & Összesen & 0,55 & 0,68 & 0,70 & 0,60 & 0,67 & 0,69 \\
\hline
\end{tabular}

A nem szerint a jogismeret mutatói 1965-ben határozott eltérést mutattak, ${ }^{5}$ mégpedig a férfiak javára. Mostani felvételünk adatainak vizsgálata az összefüggés teljes hiányát jelzi (a vizsgált öt szempont közül a legmagasabb, az összefüggést teljes egyértelmüséggel kizáró szignifikanciaszinttel). Ha az egyes jogismereti indexeket nézzük, ${ }^{6}$ akkor is hasonló eredményre jutunk. Összegezve: míg a nem szerint a jogismeretben 1965-ben igen jelentős (és bizonyára szignifikáns) különbségek voltak érzékelhetök a férfiak javára, addig ezek mára eltüntek. Ennek legnyilvánvalóbb oka lehet, hogy a nők általános képzettségi szintje megegyezik, sőt lassan meg is haladja a férfiakét, míg 1965-ben ez az arány a férfiaknál jóval magasabb volt. ${ }^{7}$

A kor tekintetében egyértelmüen szignifikáns összefüggést találunk a teljes jogismereti indexszel. Mindkét adatfelvételi időpontban egyszerre kétféle összefüggést lehet érzékelni. Egyfelöl a középkorúak az átlagnál némileg magasabb ismeretszinttel bírnak. Ugyanakkor, míg 1965-ben a fiatalok, addig az ezzel összevethető 2013-as mintában az idősebbek tüntek határozottan tájékozottabbnak. Ennek több oka is lehet. A kérdések jelentős része 1965-ben a szocialista (egy-két évtizedes múltú) jogintézményekre vonatkozott, aminek a megismerése a fiatalabbak számára természetesebb volt. Bár ez valószínüleg igaz, mégis azt találtuk, hogy az általunk feltett, vagyis nem kifejezetten szocialista jogi kérdések esetében (lásd 1965 ta oszlop) ez az összefüggés még erősebb is, vagyis biztosan nem az adatfelvétel „hibája”. Lé-

5 Az eltérés különösen jelentős azon kérdések tekintetében, amelyeket 2013-ban ismét feltettünk. Lásd a táblázat 1965 ta fejlécű oszlopát.

6 Ezek adatait táblázatos formában e dolgozatban tartalmi korlátok miatt nem közöljük.

7 Kulcsár - erősen torzító mintájában - a férfiak 10\%-a, a nők 6\%-a rendelkezett felsőfokú végzettséggel. 
nyegében hasonló összefüggést találunk az egyes jogismereti indexek esetében is. Valamennyi esetben hasonló irányú és általában legalább „egyszázalékos” (szignif $<0,01$ ), vagy annál erősebb összefüggést találunk. Különösen erős ez az államjogi kategória esetében, ahol a legidősebbek tűnnek a legtájékozottabbaknak, és a szignifikancia értéke egy ezrelék alatti, míg éppen ezen a területen voltak 1965-ben az idősek sokkal tájékozatlanabbak.

A társadalmi rétegkategóriák különösen hangsúlyos szerepet kapnak Kulcsár elemzésében - nyilvánvalóan nem függetlenül a szocialista állam, marxista, osztályalapú ideológiájától sem. Kulcsár ezen a területen valóban kiemelkedően jelentős eltéréseket talált az egyes csoportok között, a szellemiek „javára” és a mezögazdasági fizikaiak „kárára”. Ez az összefüggés a mi adatainkban is megjelenik. Ami Kulcsár 1965-ös összesített adattáblái alapján valószínüsíthető, az esetünkben bizonyosság: az öt vizsgált változó közül ez az adat mutatja a legszorosabb öszszefüggést a teljes jogismeret adatával. Ez a szoros összefüggés bármely módon számított indikátor esetében érzékelhető, amint az az 1. táblázatból is jól látható. ${ }^{8} \mathrm{Az}$ adatok ugyanakkor az ismeretszintben meglévő különbségek jól érzékelhető csökkenésére utalnak, különösen, ha azt kifejezetten az általunk alkalmazott kérdésekre vetítve nézzük az 1965 ta és 2013 sz_k oszlopok összevetésével. Ez az adat némileg meglepő, ha figyelembe vesszük, hogy a szocializmus éppen a társadalmi egyenlőtlenségek megszüntetésének jelszavával „kampányolt”, bár ennek kapcsán valaki érvelhet azzal, hogy a szocializmus építésének viszonylag korai szakaszában történt a mérés. Ebben az esetben azonban a különbségek csökkenése mögött jelentős részben az államjogi kérdések hatása áll. Míg a másik két jogterületen bár a különbségek fél évszázad alatt radikálisan csökkentek, mégis nagyon erős, abszolút szignifikáns eltérés tapasztalható a társadalmi rétegkategóriák között, noha ugyanez teljességgel hiányzik az államjogi index tekintetében.

$\mathrm{Az}$ iskolai végzettség 2013-ban a második legerősebb összefüggést mutatja a jogismeret adatával. Szoros, teljesen szignifikáns összefüggést találunk egyenként mindhárom részindikátorral is.

Némileg meglepő módon Kulcsár nem közöl adatokat a jogismereti indikátoroknak iskolai végzettség szerinti megoszlásáról. Ez az oka annak, hogy táblázatunk első oszlopa üres. Ehelyett csak a tíz kérdésre adott válaszok átlagértékeiböl általunk kalkulált adatokra hagyatkozhatunk (1965 ta). Ezekre az adatokra tekintve, a szélső értékekből kiindulva iskolai végzettség tekintetében 1965-ben a legerősebb összefüggést találjuk a jogismeret indikátorával. Az ismeretszint különbsége a legalsó és legmagasabb kategóriában 2,5-szeres, míg a társadalmi réteg kategóriában csak 1,75-szeres. Ennek oka, hogy az iskolai végzettség hétfokozatú skálájának első eleménél („nem járt iskolába”) találjuk az extrém alacsony jogismereti értéket, miközben ebbe a kategóriába csak tízen $(0,8 \%)$ tartoztak. ${ }^{9}$ A 2 . értékkel (1-7 osztályt végzett) összevetve a legmagasabb érték adatát már a társadalmi réteghez hasonló arányt kapunk.

8 Mivel 2013-as mintánkban a mezőgazdasági fizikai dolgozók aránya rendkívül alacsony (26 fő, a teljes minta alig több mint $2 \%-a)$, ezért eredményeinket teszteltük a szellemi-fizikai, kétkategóriás változón is, ám a szignifikáns összefüggés továbbra is megmarad.

9 2013-ban ez a kategória már üresen maradt. 
A táblázatból az is érzékelhető, hogy az általunk mért jogismereti kérdések tekintetében az iskolai végzettség szerinti különbségek (ha kivesszük a nagyon kicsi, általános iskolát be nem fejező csoportot) jelentősen csökkentek. Az egyes jogismereti indikátorokra tekintve az államjog esetében, és meglepő módon az eljárásjog esetében is ez a különbségcsökkenés radikális, igaz, az utóbbi esetében ebben a magasabb iskolázottságúak átlagos ismeretszintjének csökkenése is benne van. A két kérdésböl előállított polgári jogi index esetében a különbségek mintha nőttek volna, miközben az általános ismeretszint némileg növekedett. Összességében a teljes jogismereti index szoros, bár az 1965-ösnél valószínűleg gyengébb összefüggést mutat az iskolai végzettséggel. A változás a jogismeret szintjének jelentős növekedését és a különbségek csökkenését mutatja, ám ez elsősorban az államjogi ismeretek hatásának tulajdonítható.

A településkategóriák szerinti eltérések is érzékelhetőek voltak 1965-ben, amely eltérések számos társadalmi jellemző tekintetében máig fennállnak. ${ }^{10}$ Úgy tủnik azonban, hogy ez a különbség a teljes jogismeret általunk mért szintjében nem lelhető fel. Szembeötlö, hogy a falvak (általában összességében alacsonyabb iskolázottságú, idősebb) lakói a városokhoz hasonlóan teljesítenek. Az ANOVA-elemzés is azt jelzi, amit az egymáshoz közeli átlagok alapján sejthetünk: nincs szignifikáns összefüggés a teljes jogismeret és a településkategóriák között. ${ }^{11}$ Ehhez képest meglepö, hogy ha az egyes jogterületek ismeretindexeit vizsgáljuk, akkor az államjogi és polgári jogi ismeretek esetén nagyon erős (egy ezrelék alatti), de az eljárásjog indexe esetében is jelentős $(0,006)$ szignifikanciaszinttel találkozunk. Különösen az államjog esetében meglepő ez az adat, ahol ritkán találunk szignifikáns összefüggést. A szokatlan tényt, hogy a teljes mutató esetében a szignifikáns összefüggés eltünik, technikailag magyarázhatja, hogy az államjogi ismeretek esetében - némileg meglepő módon - a községek, eljárásjogi ismeretekben a városiak, míg polgári jogi ismeretekben a budapestiek tủnnek a legtájékozottabbaknak. Ezek az adatok a teljes jogismeret esetében talán kiolthatják egymást. Be kell valljuk ugyanakkor, hogy ezeknek a mintázatoknak a magyarázatára még csak plauzibilis hipotézist sem tudunk megfogalmazni. Összességében az 1965-ben, a falvak „rovására” tapasztalt és bizonyára szignifikáns jogismereti hátrány 2013-ban eltünt az általunk mért adatok alapján.

Az öt tényezőnek a jogismeret általános mértékére, illetve egyes jogterületek ismeretszintjére gyakorolt hatását elemezve néhány általános és lényeges tendencia is kirajzolódik. A jogismeret szintjének általános növekedése alapvetően határozta meg az egyes tényezők hatásának érvényesülését is. Ez a növekedés különösen jelentős volt az államjogi ismeretek (132\%), kevésbé jelentős az eljárásjogi (108\%) és a polgári jogi kérdésekből (105\%) képzett indikátoraink esetében. Az általános növekedés azonban eltérően jelentkezett az egyes szociodemográfiai csoportok tekintetében. Ezzel együtt általában a különbségek csökkenését tapasztaltuk. Különösen szembetűnő ez a „kiegyenlítődés” a nemek és a településkategóriák között, de valamennyi területen jelen van; legkevésbé a Kulcsár által alkalmazott „marxista” társadalmi rétegkategóriák és - alighanem - az iskolai végzettség esetében.

10 Lásd pl. KovÁch Imre: A vidék az ezredfordulón. A jelenkori magyar vidéki társadalom szerkezeti és hatalmi változásai. Argumentum - MTA TK SZI, Budapest, 2012.

11 Még éppen az általunk vizsgált kérdések esetében lehet erőteljesebb eltérést felfedezni. Lásd 1965 ta oszlop. 


\subsection{A khi-négyzet-adatok áttekintése}

A 2. táblázat a khi-négyzet-próba értékeit mutatja be négytizedes jegyig kerekítve. A khi-négyzet-próba arra ad választ, hogy a táblázatban elemzett két változó (itt egyfelöl a tíz jogismereti kérdés, és másfelől az öt szociodemográfiai változó) között van-e valamilyen statisztikai összefüggés. Általában akkor fogadják el egy ilyen összefüggés tényét, ha a próba értéke 0,05 alatt van. Az alábbiakban ennél némileg szigorúbb 0,01-es értéket veszünk figyelembe. Az ennél magasabb értékeket tartalmazó cellákat sötétebb színnel is jelöljük. (Ahol négy nullát látunk, ott az összefüggés rendkívül egyértelmü.)

Itt tehát visszalépünk az eredeti kérdésekhez az összevont indikátorok helyett azért, hogy az 1965-ös adatokra nézve is feltehessük az összefüggések szignifikanciájára vonatkozó kérdésünket, illetve az ezt jelző próba értékeit összevethessük a két időpontra nézve. Mindamellett az egyes jogterületekhez kapcsolódó kérdéseket ilyen csoportosításban tekintjük át.

\section{2. táblázat}

Khi-négyzet-értékek

\begin{tabular}{|c|c|c|c|c|c|c|c|c|c|c|}
\hline \multirow{2}{*}{\begin{tabular}{|l} 
Kontrollváltozó \\
Minta
\end{tabular}} & \multicolumn{2}{|c|}{ Nem } & \multicolumn{2}{|c|}{ Kor } & \multicolumn{2}{|c|}{$\begin{array}{c}\text { Iskolai } \\
\text { végzettség }\end{array}$} & \multicolumn{2}{|c|}{$\begin{array}{l}\text { Társadalmi } \\
\text { réteg }\end{array}$} & \multicolumn{2}{|c|}{ Településtípus } \\
\hline & 1965 & 2013 & 1965 & 2013 & 1965 & 2013 & 1965 & 2013 & 1965 & 2013 \\
\hline \multicolumn{11}{|l|}{ ELJÁRÁSJOGI KÉRDÉSEK } \\
\hline $\begin{array}{l}\text { Elfogadja-e a bíróság azt } \\
\text { a védekezést, ha valaki nem ismeri } \\
\text { a törvényt? }\end{array}$ & 0,0000 & 0,1761 & 0,4555 & 0,0050 & 0,0000 & 0,0811 & 0,0000 & 0,0013 & 0,0000 & 0,0001 \\
\hline $\begin{array}{l}\text { Meg lehet-e tagadni a tanúskodást } \\
\text { a bíróság elött? }\end{array}$ & 0,0000 & 0,0124 & 0,8584 & 0,0214 & 0,0000 & 0,0058 & 0,0000 & 0,0006 & 0,0000 & 0,0447 \\
\hline $\begin{array}{l}\text { Kötelezö-e ügyvéd részvétele } \\
\text { a bírósági perben? }\end{array}$ & 0,0083 & 0,0048 & 0,0176 & 0,0460 & 0,0000 & 0,0000 & 0,0000 & 0,0000 & 0,0000 & 0,0000 \\
\hline \multicolumn{11}{|l|}{ ÁLLAMJOGI KÉRDÉSEK } \\
\hline $\begin{array}{l}\text { Ki vagy milyen szervezet hozza } \\
\text { Magyarországon a törvényeket? }\end{array}$ & 0,0000 & 0,0133 & 0,0005 & 0,0000 & 0,0000 & 0,0000 & 0,0000 & 0,0003 & 0,0000 & 0,0000 \\
\hline $\begin{array}{l}\text { Hány évre választják az } \\
\text { országgyülési képviselőket? }\end{array}$ & 0,0000 & 0,0230 & 0,0024 & 0,0000 & 0,0000 & 0,0000 & 0,0000 & 0,2829 & 0,0000 & 0,8022 \\
\hline Kik választják a minisztereket? & 0,0000 & 0,0001 & 0,3417 & 0,0000 & 0,0000 & 0,0001 & 0,0000 & 0,0000 & 0,0001 & 0,0000 \\
\hline $\begin{array}{l}\text { Ki választja a helyi tanács elnökét } \\
\text { és titkárát? }\end{array}$ & 0,0000 & 0,6126 & 0,0373 & 0,0000 & 0,0000 & 0,0011 & 0,0000 & 0,1080 & 0,1435 & 0,0000 \\
\hline $\begin{array}{l}\text { Hol vezetik a születési, házassági, } \\
\text { halotti anyakönyvet? }\end{array}$ & 0,0000 & 0,0187 & 0,0000 & 0,0007 & 0,0005 & 0,3102 & 0,0000 & 0,3259 & 0,0000 & 0,0002 \\
\hline \multicolumn{11}{|l|}{ POLGÁRI JOGI KÉRDÉSEK } \\
\hline Mikor lesz valaki nagykorú? & 0,0000 & 0,8004 & 0,0000 & 0,1850 & 0,0000 & 0,1255 & 0,0000 & 0,9497 & 0,0001 & 0,0929 \\
\hline $\begin{array}{l}\text { Érvényes-e a saját kezűleg } \\
\text { írt végrendelet, ha tanúk } \\
\text { nem írták alá? }\end{array}$ & 0,0000 & 0,0018 & 0,3938 & 0,0024 & 0,0063 & 0,0000 & 0,0000 & 0,0000 & 0,0000 & 0,0000 \\
\hline
\end{tabular}


A táblázat adatai összességében alátámasztják az elöbbi elemzésünk során feltárt mintázatokat. Így különösen:

(i) A szociodemográfiai adatok 1965-ben jóval szorosabb összefüggést mutattak a jogismerettel, mint 2013-ban. Bár ez az adat így nem értelmezhető, mégis árulkodó, hogy az 1965-re számított khi-négyzet-próbák átlagos értéke $(0,045)$ jóval alatta marad a 2013-ra számított $(0,101)$ adatnak. Igaz, az eltérés jelentősen csökken, de nem tűnik el, ha az elemzésből kivesszük az államjogi ismeretek öt kérdését.

(ii) Szembeötlő itt is, hogy a „nem” mint magyarázó változó, ami 1965-ben egy kivétellel minden kérdésre tízezrelék alatti értéket mutatott, 2013-ra jórészt elveszíti jelentőségét. Kevésbé szembetűnő, de jól érzékelhető a - háromértékű - társadalmi réteg fontosságának csökkenése. Ez 1965-ben minden változó esetében tízezrelékes érték alatti, nagyon erős összefüggést mutatott, míg ilyet 2013-ban csak három esetben találunk. A településtípus szerepe továbbra is jelentős, ám csökkent.

(iii) A kor a fentiekkel szemben valamivel fontosabbá válik, igaz az szinte kizárólag az államjogi ismereteknek tudható be.

(iv) Figyelemre méltó még egyes kérdések „viselkedése” is, aminek részletes elemzésébe itt nem tudunk belemenni. Az olvasónak azonban lehetősége van az egyes adatok kapcsán hipotetikus magyarázatokat felálítani. Így pl. nehezen magyarázható, hogy a nagykorúságra vonatkozó kérdések miért mindig csak az 1965-ös adatokban mutatnak összefüggést.

\section{Az általános közéleti tájékozottságra és ezen keresztül a jogismeretre ható tényezők ${ }^{12}$}

Az 1965-ös kutatás abból a feltételezésből indul ki, hogy mai kifejezésekkel a médiafogyasztás, a társadalmi aktivitás és a politikai kérdésekben való tájékozottság mértéke szorosan összefügg a jogismeret mértékével. Ezért ezeket a tényezőket is mérték, amiként azt, a legtöbb területen, bár némileg eltérő módszerrel mi is megtettük.

\subsection{A politikai ismeretek hatása}

A politikai tájékozottságot 1965-ben 3-3 közismert magyar és külföldi politikus ismertségével mérték. ${ }^{13}$ Hasonló mutatót mi nem képeztünk, mert hasonló módszer ma tartalmilag más eredményt hozna, az adekvátabb mérés pedig meghaladta volna anyagi lehetőségeinket. Ráadásul Kulcsár tulajdonképpen maga sem közöl adatot a jogismereti és a fenti módon mért politikai ismeretszint közötti összefüggésröl.

12 Az e pontban szereplő elemzésekhez kapcsolódó adatok, mivel azok csak önmagukban, 2013-ra nézve értelmezhetőek, a 2013-as „normál” nem „korrigált” mintára vonatkoznak, kivéve, amikor kifejezetten számszerü összehasonlítást teszünk a Kulcsár által közölt adatokkal. Ezekben az esetekben a korrigált mintát használjuk.

13 A kérdés: Meg tudja-e mondani, hogy kik az alant felsorolt személyek: Kállai Gyula, Losonczi Pál, Veress Péter, Gomulka, Gromiko, Kennedy. A válaszalternatívák: nem, igen, körülbelül. Bár a kérdőívből nem derül ki, valószínűleg a válaszadóknak mondani kellett valamit, és azt a kérdezőbiztos értékelte. 
Tanulmánya 20. oldalán a szerző azt mutatja be, hogy a jogismerethez hasonlóan a politikai ismeretek esetében is, a tájékozottság mértéke a szellemitöl a mezőgazdasági fizikai dolgozók felé haladva csökken. Ez azonban, bár valószínűsíti, egyáltalán nem bizonyítja a két tényező összefüggését.

Nem akartuk azonban ezt a szempontot teljesen negligálni sem. Saját, 2013-as adatainkon ezért ezt a feltételezést úgy teszteltük, hogy szétválasztottuk azokat a jogismereti kérdéseket, amelyek kifejezetten az állami-politikai folyamatokra vonatkoztak, ${ }^{14}$ és azokat, amelyek tisztán jogi kérdések, a politikai rendszer müködésével nem függenek össze $\cdot{ }^{15} \mathrm{~A} 3$. táblázatban a Kulcsár tanulmányának 19. és 20 . oldalán közölt adatsorokat vetjük össze ezek mai megfelelöivel. Jól látható, hogy míg a társadalmi státus és a jogi, valamint a politikai ismeretek között is szoros összefüggés mutatkozott 1965-ben, addig az - legalábbis az általunk mért - politikai ismeretek tekintetében jelentősen csökkent. Ugyanakkor a két ismerettípus között a 2013-as adatainkon mért korreláció ${ }^{16}$ viszonylag magas $(0,224)$ és szignifikáns is, ami arra utal, hogy a Kulcsár által feltételezett összefüggés ma is jelen van.

\section{3. táblázat}

Jogi és politikai ismeretek indikátorai foglalkozási csoport szerinti bontásban ${ }^{17}$

\begin{tabular}{|l|c|c|c|c|}
\hline & \multicolumn{2}{|c|}{ Jogi ismeretek } & \multicolumn{2}{c|}{ Politikai ismeretek } \\
\hline & $\mathbf{1 9 6 5}$ & $\mathbf{2 0 1 3}$ & $\mathbf{1 9 6 5}$ & $\mathbf{2 0 1 3}$ \\
\hline Szellemi dolgozók & 0,61 & 0,75 & 0,86 & 0,83 \\
\hline Fizikai dolgozók & 0,53 & 0,70 & 0,74 & 0,81 \\
\hline Mezőgazdasági fizikai dolgozók & 0,50 & 0,65 & 0,59 & 0,79 \\
\hline
\end{tabular}

Összességében tehát úgy tünik - noha egyértelmű állitás az adathiányok és az összevetés esetlegessége miatt nem tehetö -, hogy a politikai és a jogi tájékozottság közötti, 1965-ben valószínüsíthetően igen jelentős összefüggés a 2013-as adatokat kevéssé jellemzi, bár továbbra is határozottan jelen van.

\subsection{A médiafogyasztás hatása a jogismeretre}

A tömegkommunikációtól azt várhatjuk, hogy általában tájékozottabbá teszik az embereket a közügyekkel és így a joggal kapcsolatban is. Ezt a hatást Kulcsár is feltételezte, és vizsgálta is a napilapok olvasása és a jogismeret közötti összefüggést elemezve. Az 1965-ös adatfelvétel során a kérdezettek óriási (megkockáztatjuk: gyanúsan) nagy többsége (66\%) járatott vagy rendszeresen vásárolt $(15 \%)$ napi-

14 Ez a négy alkotmányjogi kérdés.

15 A fennmaradó hat jogismereti kérdés.

16 A korreláció két tényező között feltételezhető lineáris kapcsolatot méri. Lineáris: minél magasabb az egyik, annál magasabb (vagy alacsonyabb) a másik tényező értéke. +1-0- -1 között mozoghat a mutatója, ahol 0 az összefüggés teljes hiányára, +1 „egyenes arányosságra”, -1 „fordított arányosságra” utal.

17 A 2013-as adatok a teljes 1000 fős mintára vonatkoznak. 
lapot saját állítása szerint. Azt találta, hogy a napilapot járatók jogismerete határozottan magasabb a rendszeresen vásárlókénál, azoké pedig a napilapot egyáltalán nem olvasókénál. Ez az összefüggés az egyes jogterületi indexek mindegyikénél jelen van, de különösen erős az államjog esetében.

A médiafogyasztás hatását mi is mérni kívántuk, ám az elektronikus média (föleg: televízió) 1965 utáni általánossá és meghatározóvá válásával, majd az internet megjelenésével a napilapok „fogyasztása” ma már nagyon rossz mutatószáma lenne a tömegtájékoztatási eszközök egyéni hatásának. Az omnibuszkérdőív állandó kérdéseiben összesen öt tévécsatorna (3 országos, 2 hír), két rádió, hétféle napilap és négy hírportál fogyasztására kérdeztek rá, valamint az interneten töltött teljes időre. E nagyszámú médium hatását többféle módszerrel vizsgáltuk.

Az egyenkénti korreláció adatait a 4. táblázat tartalmazza.

\section{4. táblázat}

A jogismeret és a médiafogyasztás közötti kapcsolat.

Korrelációs adatok (a cellákban felül a Pearson-féle R, alul szignifikanciaszint)

\begin{tabular}{|c|c|c|c|c|}
\hline & \multicolumn{4}{|c|}{ Jogismereti mutatók } \\
\hline & Teljes & Államjogi & Eljárásjogi & Polgári jogi \\
\hline \multirow{2}{*}{ Magyar Televízió } &,- 048 &,- 008 &,- 056 &,- 002 \\
\hline & ,132 & ,792 & ,081 & ,952 \\
\hline \multirow{2}{*}{ TV2 } &,- 029 & ,047 &,- 056 &,- 015 \\
\hline & 365 & , 141 & 077 & ,635 \\
\hline \multirow{2}{*}{ RTL Klub } &,- 044 & 017 &,- 073 &,- 005 \\
\hline & , 170 &, 596 & ,022 & ,872 \\
\hline \multirow{2}{*}{ ATV } & 035 &,- 035 & ,068 & ,005 \\
\hline & ,290 & ,290 & ,039 & ,874 \\
\hline \multirow{2}{*}{ Hír TV } & 049 &, 008 & 051 &, 053 \\
\hline & , 136 & ,807 &, 126 &, 111 \\
\hline \multirow{2}{*}{ Kossuth Rádió } &,- 084 &,- 063 &,- 077 & ,007 \\
\hline & 011 & ,060 & ,020 & ,837 \\
\hline \multirow{2}{*}{ Klubrádió } & 074 &,- 024 & ,075 & ,085 \\
\hline & ,038 & ,494 & ,035 &, 018 \\
\hline \multirow{2}{*}{ Blikk } & ,116 &,- 002 & ,131 & ,051 \\
\hline &, 000 & ,947 &, 000 & ,107 \\
\hline \multirow{2}{*}{ Magyar Hírlap } & ,071 &,- 026 &, 069 & ,112 \\
\hline & 024 & ,414 & ,030 & ,000 \\
\hline \multirow{2}{*}{ Magyar Nemzet } & ,040 &,- 085 & ,050 & , 120 \\
\hline & ,208 & ,007 & ,115 & ,000 \\
\hline \multirow{2}{*}{ Metropol } & ,099 &,- 049 & , 125 & ,071 \\
\hline & ,002 & ,122 & ,000 & ,025 \\
\hline
\end{tabular}




\begin{tabular}{|l|c|c|c|c|}
\hline \multirow{2}{*}{ Népszabadság } & \multicolumn{4}{|c|}{ Jogismereti mutatók } \\
\hline \multirow{2}{*}{ Népszava } & Teljes & Államjogi & Eljárásjogi & Polgári jogi \\
\cline { 2 - 5 } &, 028 &,- 036 &, 005 &, 129 \\
\hline \multirow{2}{*}{ Helyi, megyei lap } &, 370 &, 259 &, 871 &, 000 \\
\cline { 2 - 5 } &, 025 &,- 041 &, 013 &, 117 \\
\hline \multirow{3}{*}{ Index } &, 425 &, 200 &, 677 &, 000 \\
\hline \multirow{2}{*}{ Origo } &, 109 &,- 023 &, 137 &, 053 \\
\hline \multirow{2}{*}{ Hvg.hu } &, 001 &, 468 &, 000 &, 094 \\
\cline { 2 - 5 } &, 133 &, 007 &, 140 &, 117 \\
\hline \multirow{2}{*}{ Mno.hu } &, 000 &, 824 &, 000 &, 000 \\
\hline \multirow{2}{*}{ Nol.hu } &, 137 &, 024 &, 138 &, 096 \\
\hline &, 000 &, 447 &, 000 &, 002 \\
\hline &, 150 &, 018 &, 171 &, 084 \\
\hline &, 000 &, 569 &, 000 &, 008 \\
\hline &, 126 &, 018 &, 137 &, 090 \\
\cline { 2 - 5 } &, 000 &, 568 &, 000 &, 004 \\
\hline
\end{tabular}

Az egyes médiumtípusokból külön változókat képeztünk. ${ }^{18}$ Azt találtuk, hogy a médiafogyasztás szignifikánsan növeli a jogismeretet, bár a hatás nem túl erős. Emögött a média eltérő jellege áll, amit három külön csoportban vizsgáltunk. Egyértelműen legerősebb a hírportálok „pozitív” hatása $(R=0,162$; szf. $<0,001)$, ezt követi még mindig határozott hatást mutatva a napilapok olvasása $(R=0,111$; szf. $<0,001)$, majd az összefüggés teljes hiányát jelző elektronikus média $(R=-0,010$; szf. $=0,777)$. Mindehhez azonban figyelembe kell venni a fogyasztók számát is. Hírportálokat egyáltalán nem olvas a válaszadók 55\%-a, napilapot 39\%, míg tv-t csak a válaszadók mintegy $2 \%$-a nem néz. Ez tartalmilag árnyalja a fenti képet. Módszertanilag pedig arra figyelmeztet, hogy a látszólagos közvetlen összefüggés mögött egy harmadik tényező húzódhat meg: az aktív információkeresők/befogadók vannak inkább jelen a napilapok és a hírportálok világában, akik emiatt az attitüdjük miatt (tehát nem feltétlenül a „fogyasztás” okán) eleve tájékozottabbak is. Egy másik alternatív, bourdieu-i magyarázat azt mondhatná, hogy a jelentős kulturális és gazdasági tőkével rendelkezők (ti. van pénze az ingyen hozzáférhető médián túli források megfizetésére is) eleve tájékozottabbak, amit az információforrásokhoz való nagyobb hozzáférése folyamatosan újratermel. ${ }^{19}$ Ám ezzel némileg túllépünk elemzésünk szük határain.

18 Az egyes kérdések válaszalternatívái általában 0 (soha) és naponta 4 (illetve elektronikus médiánál 5) alkalom között voltak. A változókhoz ezeket az értékeket adtuk össze, médiatípusonként, illetve a teljes fogyasztásra nézve.

19 Bourdieu, Pierre: A társadalmi egyenlőtlenségek újratermelődése. Gondolat, Budapest, 1978; BouRDIEU, Pierre: A gyakorlati észjárás. Napvilág, Budapest, 2002, 17, 31-44. 
Az érdeklődő elmélyedhet a táblázat egyes sorainak adataiban is. Az elektronikus médiában még a hírcsatornák sem mutatnak igazán erős összefüggést a jogismeret változóival, s megdöbbentő módon különösen nem az államjogi ismeretek esetében. A média egészére nézve egy olyan változót hoztunk létre, amely az egyes médiumokat „szórakoztató - is-is - tájékoztató” kategóriákba sorolva vette figyelembe, a szórakoztató fogyasztását negatív, az is-is kategóriát nulla, míg a tájékoztatót pozitív értékkel elemezve..$^{20} \mathrm{Az}$ így képzett változó határozottan erősebb korrelációt $(R=0,134)$ mutat az általános jogismerettel, mint a médiafogyasztást súlyozatlanul figyelembe vevő változó $(R=0,099)$, ám a különbség viszonylag alacsony foka, valamint a tény, hogy ez a változó sem magyarázza az államjogi ismeretek szórását, azt jelzi, hogy a lényegi sajátságokat nem sikerült megragadnunk. Képzett változónk magyarázó erejét az is ronthatja, hogy a közszolgálati média összességében negatív, bár a legtöbb esetben nem szignifikáns összefüggést mutat a jogismeret majd minden változójával.

Érdekes, hogy a napilapok esetében összefüggés épp ott érzékelhetö, ahol talán a legkevésbé várnánk (Blikk, Metropol, megyei lapok). Ezzel szemben a valamely politikai oldalhoz köthető napilapok általában „gyengén teljesítenek”, egészen az olyan szélsőséges értékekig, mint az államjogi ismeretek tekintetében már szignifikáns negatív összefüggés. Ezt is megkíséreltük tesztelni a - szórakoztató-tájékoztató - változóhoz hasonlóan létrehozott, kormánypárti-ellenzéki média felosztással. Ám ez a mutató $(R=0023$; szf. $=0,530)$ semmilyen kapcsolatot nem mutat a teljes jogismerettel vagy bármely más jogismereti mutatóval.

Úgy tünik, és ezt a szakirodalom is alátámasztani látszik, ${ }^{21}$ hogy a média egyre kevésbé a tájékoztatás és egyre inkább a szórakoztatás eszközévé válik. Különösen áll ez a televíziózásra és jelentős részben az internethasználatra is. ${ }^{22}$ Éppen ezért nem önmagában a médiafogyasztás mértéke, hanem csak a tájékoztatásra (is) törekvő média (elsősorban a napilapok, de különösen a hírportálok) használata növeli a jogismeretet; illetve bemutattuk egy alternatív, harmadik, mögöttes tényezöre vonatkozó magyarázat lehetőségét is.

A 2013-as adatok egy a fél évszázaddal korábbitól gyökeresen eltérő képet mutatnak. A technológiai változásokon túl, ennek oka nyilván a média megváltozott funkciójában, valamint a (párt)állam, a média és a jog közötti, 1990 után megváltozott összefüggésrendszerben keresendő.

20 A létrehozás képlete lehetne: $-1^{*}\left(\sum\right.$ [inkább szórakoztató média] $)+\sum$ [inkább tájékoztató média]. Két kutató független, majd egyeztetett besorolása alapján.

21 Lásd HABERMAS, Jürgen: A társadalmi nyilvánosság szerkezetváltozása. Századvég, Budapest, 1993; Nothstine, William L.-Blair, Carole-Copeland, Gary (eds.): Critical questions: Invention, creativity, and the criticism of discourse and media. St. Martin's Press, New York, 1994, 3-9.

22 Azt találtuk ugyanis, hogy az interneten töltött idő, önmagában, semmiféle kapcsolatot nem mutat a jogi tájékozottsággal. 


\subsection{A társadalmi szervezeti tagság hatása a jogismeretre}

Az 1965-ös vizsgálat kiterjedt a „társadalmi szervezetekben végzett aktív munka” hatására is. ${ }^{23}$ Ennek kapcsán Kulcsár a tanácstagi, valamint a szakszervezeti és pártfunkciót (tehát nem a tagságot) vette figyelembe. llyen pozíciókban a megkérdezettek összesen alig több mint 10\%-a volt (29, 94, 16 fö az 1217-böl). Kulcsár tanulmányának 11. táblázatában közölt adatai azt mutatják, hogy a valamilyen pozíciót betöltő személyek jogismerete átlagosan jóval magasabb, mint a „passzívaké”, ez az eltérés azonban meghatározóan az államjogi ismeretek magasabb szintjéből következik, más jogterületeken az összefüggés láthatóan jóval gyengébb.

Ez az a terület, amely a rendszerváltás hatására szinte teljesen megváltozott. Az egy párt helyett sok jelent meg (egy időre), a szakszervezet kvázi kötelező jellege megszűnt stb. Mindezt adataink is igazolják. Jól jelzi ezt, hogy politikai szervezethez tartozónak mindössze 9, szakszervezeti tagnak (tehát egyik esetben sem vezetőnek-,funkcionáriusnak”) 17 fö, egyházi szervezet tagjának (legtöbben) 45 fö vallotta magát. A válaszadók $88 \%$-a azonban, jól reprezentálva ebben is a magyar társadalom jellemzőit, semmiféle társadalmi aktivitásban nem vett részt, kettőnél több szerveződésben csak 6 fő vesz részt. Az így értelmezett kvázi aktívak aránya egyezik meg nagyjából azzal, amit Kulcsár a funkcionáriusok (vezetők, tanácstagok) esetében mért.

Az adott helyzetben az tünt a legjobb módszernek, ha a „passzívak” és „aktívak” (legalább egy szervezetben tevékenykedők) átlagos jogismeretszintjét vetjük össze. Itt azt találtuk, hogy az aktívak minden területen legalább kis mértékben tájékozottabbak. Az eltérést ANOVA-módszerrel vizsgálva a teljes jogismeret $(\mathrm{szf} .=0,011)$ és az eljárásjog esetében (szf. $=0,003$ ) határozottan kimutatható összefüggés van, míg - éles ellentétben az 1965-ös adatokkal - épp az államjog területén ennek nyoma sincs. Meg kell azonban jegyezni, hogy adataink szerint a társadalmi aktivitás jogi aktivitással is együtt jár. A két tényező között erős, egyezrelékes szignifikanciával bíró korreláció van. ${ }^{24}$ Elképzelhető tehát, hogy a szervezeti tagság ezen keresztül és nem önmagában áll kapcsolatban a jogismerettel.

Összegezve: a „társadalmi aktivitás” és jogismeret összefüggése első ránézésre hasonló a két adatfelvételben. Emögött azonban jelentős eltérés tapasztalható, ami a statisztikai elemzés szintjén abban mutatkozik meg, hogy a teljes jogismereten belül más jogterületeken mutatható ki a növekedés - az államjogban 1965-ben és az eljárásjogban 2013-ban. Utóbbi mögött pedig valójában egy másik tényező (az „általános és/vagy jogi aktivitás”) áll. Végső soron pedig arról van szó, hogy hasonló név alatt egészen más jelenséget (kvázi állami funkció vs. önkéntes aktivitás) mérünk.

23 Kulcsár Kálmán: A jogismeret vizsgálata. MTA JTI, Budapest, 1967, 30.

24 Nem tudjuk, hogy ez társadalmi aktivitásukból következik-e (pl. pert indítanak valamilyen közügy érdekében), vagy egyszerüen „általános aktivitásuk” a társadalmi szervezetekre és a jogrendszerre is kiterjed, esetleg más magyarázza ezt az összefüggést. 


\section{Tapasztalat a jogrendszerben és ennek hatása a jogismeretre}

A Kulcsár által is vizsgált magyarázó tényezök harmadik csoportjában elsősorban olyan kérdések vannak, amelyek arra vonatkoznak, hogy az érintettek hogyan kerültek már kapcsolatba a joggal; akár az írott jogrendszerrel, akár a jog intézményes struktúráival, elsősorban a bírósággal. Kulcsár tanulmányában ezek közül egy kérdés esetében vizsgálta annak összefüggését a jogismeret mértékével. Az 5. táblázatban ezeket az adatokat vetjük össze a két időpontra vonatkozóan.

\section{5. táblázat}

A törvények olvasása és a jogismeret összefüggése két időpontban ${ }^{25}$

\begin{tabular}{|l|c|c|c|c|}
\hline & \multicolumn{2}{|c|}{1965} & \multicolumn{2}{c|}{2013} \\
\hline & Olvasott törvényt & Nem olvasott & Olvasott törvényt & Nem olvasott \\
\hline Államjog & 0,50 & 0,36 & 0,82 & 0,81 \\
\hline Polgári jog & 0,57 & 0,51 & 0,62 & 0,62 \\
\hline Eljárásjog & - & - & 0,71 & 0,58 \\
\hline Büntetőjog & 0,60 & 0,55 & - & - \\
\hline Teljes & $(\approx 0,56)$ & $(\approx 0,47)$ & 0,73 & 0,67 \\
\hline $\mathrm{N}$ & 933 & 284 & 529 & 677 \\
\hline
\end{tabular}

Fontos megjegyezni, hogy 1965-ben a válaszadók - ha válaszaiknak hinni lehet, ami egyébként erösen kérdéses - 87\%-a olvasott már törvényt, míg manapság ez az adat $43 \%$, a korábbi mintegy fele. Sajnos a táblázatból számos adat teljesen hiányzik, mivel Kulcsár itt a teljes jogismereti indikátort sem közli. (Ezt a három közölt adat átlagából számított adattal pótoljuk, ami a tényleges adattól nem térhet el jelentősen.) Csak az államjog és a polgári jog esetében van egyáltalán összevethető adatunk, épp ott, ahol 2013-ban nem találtunk összefüggést. Összességében adataink - a módszertani korlátok mellett - arra utalnak, hogy a törvény olvasása mindkét időpontban pozitív összefüggést mutat a jogismerettel, ám ennek mértéke 2013-ban kisebb, és a jogterületenként kimutatható hatás is alapvetően eltérö lehet. E tekintetben az államjog esetében nagy bizonyossággal állíthatjuk, hogy az 1965ben szorosan összefüggött a törvények olvasásával, míg 2013-ban - nyilván e kérdések általános ismertsége okán - ilyen összefüggés egyáltalán nincs.

Természetesen a jogrendszerrel kapcsolatban szerzett tapasztalat hatását mélyebben is elemezni kívántuk, ám erre csak a 2013-as adatok esetében volt valódi lehetőségünk. Ehhez egy, a ,jogi tapasztalat"-nak nevezhetö változót képeztünk, amely együttesen (additív módon) veszi figyelembe a törvény olvasása mellett a bírói eljárásban való részvétel és az ügyvéddel, közjegyzővel történt kapcsolatfel-

25 A táblázatban a korrigált mintából számított adatok találhatók, amelyek az indexek átlagértékeit mutatják. A normál minta alapján az összefüggés erőteljesebben jelen van. Az ezekre az adatokra elvégzett ANOVAelemzés a teljes és az eljárásjogi ismeretek mutató esetében teljességgel szignifikáns, míg a másik két tényező között semmilyen érdemi összefüggés nem mutatkozik. 
vételre vonatkozó változók adatait is. Az így képzett változónak a négy jogismereti indikátorral való lineáris összefüggését vizsgáltuk a korreláció módszerével. A korrelációs együtthatók a következők voltak: Teljes jogismeret: $R=0,274$; Államjogi: $R=$ 0,097 ; Eljárásjogi: $R=0,266$; Polgári jogi: $R=0,119$, három esetben egyezrelékes, az államjog esetében 0,002 szignifikanciával. ${ }^{26} \mathrm{Az}$ az összefüggés más tényezőkkel összevetve is viszonylag erőteljesnek módható, és elvileg-logikailag valószínűsíthetjük, hogy közvetlenül - nem más változók hatásán keresztül - hat a jogismeretre.

\section{4. Összegzö elemzés: jogismeret ma és tegnap}

\subsection{Módszertani elemzés}

A tanulmányban elsősorban történeti elemzésre vállalkoztunk. Az ilyen jellegü összehasonlítás számos metodológiai és praktikus módszertani problémát is felvet. E kutatásban ez talán a megszokottnál is nagyobb mértékben jelentkezett. Összességében azonban úgy véljük, hegy ezeket sikerült kezelnünk, elsősorban azzal a megoldással, hogy 2013-ra az összehasonlításhoz többféle „verziót” is összeállítottunk, és bár a szövegben ezt nem mindig jeleztük, folyamatosan teszteltük azokat egymás ellenében is. A jogismeret indexei kapcsán jelentkező fő problémát (sokkal kevesebb kérdésre alapozott indexek) kellö óvatossággal korrigáltuk. A jogismereti adatokat más tényezőkkel vizsgálva általában a várt összefüggéseket kaptuk, számos esetben a Kulcsár által detektált összefüggéseket ismertük fel, illetve, ahol határozott eltérés jelentkezett, ott annak a történeti változásokra vonatkozó ismereteinkkel alapvetően megegyező tendenciákat véltünk felfedezni. E tekintetben különösen a polgári jogi ismeretek szintjét mérő változó problematikus a kis kérdésszám és a kérdések önmagukban vett sajátos viselkedése miatt.

Összességében úgy véljük, hogy a történeti összevetés módszertanilag megalapozott és értelmes, értelmezhető eredményekre vezetett a két adatfelvétel között eltelt mintegy fél évszázad távlatából.

\subsection{A tanulmány eddigi eredményeinek összegzése}

Az adatfelvétel alapadatait korábbi tanulmányunkban mutattuk be. Általánosságban azt találtuk, hogy a jogismeret szinte minden kérdés esetében nött, összességében mintegy 26\%-kal. Ez valamennyi vizsgált jogterületre (közjog, polgári jog, eljárásjog) igaz, ám meghatározó az alkotmányjogi kérdések sokkal magasabb ismeretszintje, ahol a növekedés $71 \%$-os.

A további részekben három alfejezetre bontva elemeztük azt, hogy a különféle tényezők, ún. magyarázó változók milyen összefüggést mutatnak a jogismeret mértékével, az azt mérő indexekkel, illetve ezek az összefüggések miként változtak az

${ }^{26}$ A korrigált mintában az állam- és polgári jogi ismeretek nem mutatnak összefüggést. 
utóbbi fél évszázadban. Az ezzel kapcsolatos eredményeket szöveges formában összegzi a 6. táblázat.

6. táblázat

Az elemzett magyarázó változók és azok legfontosabb jellemzői

\begin{tabular}{|l|l|l|}
\hline \multicolumn{1}{|c|}{ Változó } & \multicolumn{1}{|c|}{ Hatása 2013-ban } & \multicolumn{1}{c|}{ Eltérés 1965-höz képest } \\
\hline Nem & Minimális & $\begin{array}{l}\text { Eltünt a nemek közötti, férfiak ,javára” } \\
\text { meglévő különbség. }\end{array}$ \\
\hline Kor & Talán gyengébb & $\begin{array}{l}\text { Átalakult, a fiatalok kevésbé, az idősek } \\
\text { inkább tájékozottak. }\end{array}$ \\
\hline Társadalmi réteg & $\begin{array}{l}\text { Erös, lineáris, pozitív (minél magasabb } \\
\text { státus, annál magasabb jogismeret) }\end{array}$ & Hatása talán valamelyest csökkent. \\
\hline Iskolai végzettség & Erős, lineáris & $\begin{array}{l}\text { Hatása mindkét idöpontban jelentős, ta- } \\
\text { lán nött. }\end{array}$ \\
\hline Település típusa & Minimális a teljes jogismeretre & $\begin{array}{l}\text { Jelentős csökkenés. Az egyes jogági is- } \\
\text { meretszintben jelen van, de az sem egy- } \\
\text { értelmüen lineáris. }\end{array}$ \\
\hline Politikai ismeretek & Jelen van, lineáris, pozitív & $\begin{array}{l}\text { Hatása a jelek szerint jelentősen csök- } \\
\text { kent. }\end{array}$ \\
\hline Médiafogyasztás & $\begin{array}{l}\text { Gyenge, ellentmondásos, nem feltétlen/ } \\
\text { mindig pozitív }\end{array}$ & $\begin{array}{l}\text { A mérés nehezebb. Az 1965-ben meg- } \\
\text { lévő egyértelmü és erös hatás ma nem } \\
\text { mutatható ki. }\end{array}$ \\
\hline Szervezeti tagság & $\begin{array}{l}\text { Érzékelhetö, lineáris, pozitív, ám mégis } \\
\text { bizonytalan összefüggés }\end{array}$ & $\begin{array}{l}\text { Jelentése, mérésének módja más, és } \\
\text { (ezért?) mások az érintett jogterületek } \\
\text { (akkor: államjog, ma: eljárásjog). }\end{array}$ \\
\hline Jogi tapasztalat & $\begin{array}{l}\text { Határozott, erős, lineáris, pozitiv hatás } \\
\text { - értelemszerüen, de kizárólag az eljá- } \\
\text { rásjogban }\end{array}$ & $\begin{array}{l}\text { 1965-ben feltételezett, nem tesztelt, de } \\
\text { valószínü összefüggés. Nem összevet- } \\
\text { hetö. Akkor az államjogra látszott na- } \\
\text { gyobb hatást gyakorolni. }\end{array}$ \\
\hline
\end{tabular}

Összességében azt tapasztaltuk, hogy a jogismeretszint általános emelkedése mellett a magyarázó változókkal kimutatható összefüggés a legtöbb esetben csökkenni látszik, a demográfiai adatok esetében pedig talán meg is fordult.

\subsection{Teljes jogismeret ma és régen}

Empirikus, történeti jogismereti vizsgálódásunk végső kérdése talán az lehetne, hogy vajon nőtt-e a jogismeret 1965-höz képest? A kérdést bizonyos értelemben megválaszoltuk, amikor azt találtuk, hogy a teljes jogismeret-mutató értéke magasabb 2013-ban, mint volt 1965-ben.

Ám ennek az állításnak egy gyakorlati és egy elméleti tényező is csökkenti a megbízhatóságát. Gyakorlati oldalról az 1965-ös mintavétel korlátai jelentenek problémát. Különösen a következök:

(i) Az iskolai végzettség szerinti torzitás, amely szerint a kérdezettek adatai a tár- 
sadalom tényleges összetételénél jóval jobbak voltak. Emiatt az 1965-ös közölt adat a ténylegesnél jobb, a számított időbeli növekedés pedig gyengébb.

(ii) A mintából teljességgel hiányoznak a kis- és közepes, illetve nem jogi egyetemi városok adatai, másként fogalmazva, a jogi egyetemi városok és Budapest adatai rendkívül felülreprezentáltak. Mivel ezeken a településtípusokon gyaníthatóan (és ezt Kulcsár elemzésének számos adata is jelzi) a jogismeret jóval magasabb a másutt tapasztalhatónál, ez is a ténylegesnél jobb 1965-ös adathoz, így gyengébb növekedési rátához vezet.

(iii) Az inaktívak kihagyása a mintából, ami a fentiekhez hasonlóan, gyaníthatóan a valóságosnál magasabb jogismereti adatot mutat.

Elméleti oldalról az a probléma vethető fel, hogy mivel a jogismeret szorosan kötődik az iskolai végzettséghez, ez utóbbi növekedése mennyiben magyarázza a jogismeret növekedését az elmúlt 48 évben. Joggal érvelhet valaki amellett, hogy a magasabb össztársadalmi jogismereti adat valójában nem az „emberek” általában magasabb jogismereti szintjéböl következik, hanem egyszerüen abból, hogy a felfelé mobilitás, ${ }^{27}$ különösen az iskolázottság eltolódása miatt nagyobb arányban vannak magasabb jogismereti szintű csoportok ma, mint akkor. Noha ez az érvelés erősen vitatható, érdemes megnézni, hogy valóban csak erről van-e szó. Ezeket a kérdéseket kíséreljük meg modellszámításokkal áttekinteni a következő négy pontban.

\subsubsection{Iskolai végzettség szerinti korrekció}

Ebben a pontban megkíséreljük egyfelől Kulcsár adataira, másfelől az 1960-as és 1970-es népszámlálás adataira támaszkodva meghatározni, hogy mekkora lett volna a jogismeret mutatóinak mértéke, ha az iskolai végzettség adatai nem lettek volna olyan rendkívüli mértékben torzak. Ehhez a két népszámlálás iskolai végzettség adatainak átlagát vesszük figyelembe. Az itt alkalmazott kategóriák megfeleltethetők a Kulcsár által alkalmazottnak azzal a kivétellel, hogy a felsőfokú tanulmányokat diploma nélkül zárók kategóriája hiányzik. E csoportot, amely egyébként is csak 15 főt számlál, az egyetemet végzettek kategóriájához soroljuk. A tényleges megoszlásokkal súlyozzuk aztán az egyes csoportok (az 1965 ta jelü táblázatoszlopból képzett) jogismeretszint adatait. Az így elvégzett számítások eredményét mutatja a 7. táblázat.

\section{7. táblázat}

Az 1965-ös minta iskolai végzettség szerinti torzításának kiküszöbölése

\begin{tabular}{|l|c|c|c|c|}
\hline \multirow{2}{*}{} & \multicolumn{4}{|c|}{ Jogismereti mutatók } \\
\cline { 2 - 5 } & Teljes & Államjogi & Eljárásjogi & Polgári jogi \\
\hline 1965 - Közölt adat (Kulcsár adatai alapján) & 0,599 & 0,536 & 0,615 & 0,58 \\
\hline $\begin{array}{l}\text { 1965 - Korrigált adat } \\
\text { (az időszak tényleges megoszlása szerint) }\end{array}$ & 0,530 & 0,451 & 0,532 & 0,541 \\
\hline 2013-as adat (a reprezentatív ezerfős mintán) & 0,672 & 0,754 & 0,637 & 0,593 \\
\hline
\end{tabular}

27 AndoRKa Rudolf: A társadalmi mobilitás változásai Magyarországon. Gondolat, Budapest, 1982. 


\begin{tabular}{|l|c|c|c|c|}
\hline \multirow{2}{*}{} & \multicolumn{4}{|c|}{ Jogismereti mutatók } \\
\cline { 2 - 5 } & Teljes & Államjogi & Eljárásjogi & Polgári jogi \\
\hline $\begin{array}{l}\text { Időbeli változás (2013/1965) (Kulcsár adatai } \\
\text { alapján) \% }\end{array}$ & $112 \%$ & $141 \%$ & $104 \%$ & $102 \%$ \\
\hline $\begin{array}{l}\text { Időbeli változás (2013/1965) „korrigált” adatok } \\
\text { szerint \% }\end{array}$ & $127 \%$ & $167 \%$ & $120 \%$ & $110 \%$ \\
\hline
\end{tabular}

Az adatok nyilvánvalóvá teszik, amit eddig is sejtettünk: ha a mintavétel hibáját az iskolai végzettség tekintetében korrigáljuk, akkor a jogismereti adatok 1965-re nézve a Kulcsár tanulmányában közölteknél jóval gyengébbek lettek volna. A változást tekintve a teljes jogismereti mutató tekintetében ez azt jelenti, hogy a korábban számított 12 százalékos ismeretnövekedés valójában ennek kétszerese, 27\%-os. Az államjogi ismeret esetében közel kétharmados a növekedés, míg a két másik jogterületen a növekedés a „hibahatár közeli” értékről meggyőző, egy- és kéttizednyi szintre emelkedik a torzítás korrekciója után.

\subsubsection{Településtípus szerinti korrekció}

A településkategóriák esetében, népszámlálási adatok hiányában az 1963-as mikrocenzus adataira támaszkodtunk. ${ }^{28} \mathrm{Az}$ eredeti mintában a kis- és középvárosok teljességgel hiányoznak, helyette a „városok” kategóriában a két jogi egyetemi várost találjuk, amelyek ismeretindex-adatai Budapesthez hasonlóak, nemritkán annál magasabbak is. A budapestiek mintegy két és félszeresen felül, a falvak kétharmaddal alul vannak reprezentálva az 1963-as adatokhoz viszonyítva. Mindezt úgy korrigáljuk, hogy a településszint tényleges (1963-as) adataival súlyozzuk a meglévő budapesti és falusi - az 1965 ta táblázatoszlopból kalkulált - ismeretadatokat, míg a városokra a rendelkezésünkre álló, falu és város közötti átlagértékekkel számolunk, alighanem a ténylegesnél magasabb ismeretszintet feltételezve a városokban.

\section{8. táblázat}

Az 1965-ös minta településtípus szerinti torzításának kiküszöbölése

\begin{tabular}{|l|c|c|c|c|}
\hline & \multicolumn{4}{|c|}{ Jogismereti mutatók } \\
\hline & Teljes & Államjogi & Eljárásjogi & Polgári jogi \\
\hline 1965 - Közölt adat & 0,600 & 0,536 & 0,615 & 0,580 \\
\hline 1965 - Korrigált adat & 0,541 & 0,496 & 0,529 & 0,536 \\
\hline $2013-$ as adat & 0,670 & 0,754 & 0,631 & 0,591 \\
\hline Időbeli változás (Kulcsár alapján) \% & $112 \%$ & $141 \%$ & $103 \%$ & $102 \%$ \\
\hline Időbeli változás „kikorrigált” \% & $124 \%$ & $152 \%$ & $119 \%$ & $110 \%$ \\
\hline
\end{tabular}

Ebben az esetben is azt találjuk, hogy az arányos mintavétel esetén minden bizonnyal jelentősen alacsonyabb lett volna mind a teljes, mind az egyes részterüle-

28 Az 1963-as mikrocenzus adatai. Statisztikai Kiadó Vállalat, Budapest, 1964, 37. 
tekre vonatkozó jogismereti mutató. Így a valóságos ismeretszint-növekedés is jóval jelentősebb.

\subsubsection{Egy korrigált 1965-ös minta hipotetikus végeredménye}

A fenti két szemponton túl az 1965-ös minta az inaktívak kihagyása miatt tér még el a 2013-as adatoktól. Az említett mikrocenzus adatai szerint ${ }^{29}$ a teljes lakosság 10071700 fö volt, ebböl inaktív 1147 450, nyugdíjas pedig 1085600 fö. ${ }^{30} \mathrm{Ha}$ ennek a csoportnak a jogismeretét a „60 éven felüliek” kategóriájával azonosítjuk, akik mintegy hat százalékponttal az átlag alatt „teljesítettek” viszonylag általánosan valamennyi jogismeret-mutató tekintetében, akkor ennek összhatását abban látjuk, hogy a tényleges társadalmi jogismeret emiatt is mintegy $1 \%$-kal alacsonyabb a mintából számítottnál. Ez az eltérés olyan alacsony, hogy külön táblázatot nem szentelünk neki.

Mint már jeleztük, a fenti három torzítást nem lehet együttesen kezelni, elsősorban azért, mert nem tudjuk, hogy a településtípus szerinti eltéréseket mennyire befolyásolják az e települések lakóinak iskolai végzettség szerinti összetételének eltérései. Mindamellett úgy becsüljük, hogy összességében, a teljes jogismeret indikátorban közel tíz százalékponttal (vagyis közel 20\%-kal) magasabb az 1965-ös adatok kapcsán közölt eredmény, mintha azt egy, a 2013-ashoz hasonló reprezentatív mintavétellel vették volna fel. (És ebben, a joghallgató kérdezőbiztosok esetleges, megbecsülhetetlen torzító hatását nem számítottuk bele.) A teljes jogismeret így valószínüleg mintegy harmadával volt magasabb 2013-ban, mint 1965-ben.

A kérdés már csak az, hogy ez az emberek jog iránti nagyobb érdeklődésének, aktívabb jogi tájékozódásának tudható be, vagy egyszerüen csak az iskolai végzettség általánosan magasabb szintjének mintegy mellékhatása. A következő pontban ezt vizsgáljuk.

\subsubsection{A jogismeret eltérése az iskolai végzettség eltérésének kiküszöbölésével}

A kérdés megválaszolásához az 1965-ös korrigált adatokat (7. táblázat 2. sora) vetjük össze azzal az adattal, amely azt mutatja meg, hogy ettöl mennyire tértek volna el az 1965-ös adatok, ha az egyes kategóriákban a 2013-as ismeretszint-mutatókat használjuk. ${ }^{31} \mathrm{Az}$ eredményeket a 9. táblázat tartalmazza.

29 Az 1963-as mikrocenzus adatai, 53.

30 A gyerekek az „aktív eltartottak” között szerepelnek.

31 A nem járt iskolába kategóriában a jelenlegi 1-7 osztályos kategória felével számolunk, meglehetősen konzervatív módon. A felsőfokú intézményt látogatók, de diplomát nem szerzetteket pedig itt is diplomásokként kezeljük. 


\section{9. táblázat}

Az iskolai végzettség 1965-ös, de a kategóriaértékek 2013-as adataival számolt táblázat

\begin{tabular}{|l|c|c|c|c|}
\hline & \multicolumn{4}{|c|}{ Jogismereti mutatók } \\
\hline & Teljes & Államjogi & Eljárásjogi & Polgári jogi \\
\hline $\begin{array}{l}\text { A 2013-as kategóriánkénti ismeretszintek, } \\
\text { az 1965-ös iskolaivégzettség-összetétellel számolva }\end{array}$ & 0,560 & 0,675 & 0,460 & 0,538 \\
\hline 1965 - Tényleges (mintavételi torzítás korrekciójával) & 0,530 & 0,451 & 0,532 & 0,541 \\
\hline Eltérés & $106 \%$ & $150 \%$ & $87 \%$ & $99 \%$ \\
\hline
\end{tabular}

Ha tehát az 1965-ös és a 2013-as adatok közötti eltérésröl leválasztjuk azt a hatást, amely egyszerüen az iskolai végzettség szintjének emelkedéséből következik, akkor a kép ismét jelentősen átalakul. A teljes jogismeret-mutatót tekintve viszonylag alacsony, 6\%-os javulást tapasztalunk, ami azonban kizárólag az államjogi, ezen belül az alkotmányjogi ismeretek robbanásszerü növekedésének tudható be. E hatást leválasztva az eljárásjogi kérdésekben jól érzékelhető csökkenés, míg a polgári jogi ismeretekben stagnálás lenne észlelhető.

\subsection{A magyarázó változók hatása a jogismeretre}

Kulcsár kutatását követve a teljes jogismeretre esetlegesen ható tényezőket elemeztünk. Ezek mellett most további két olyan tényezőt is bevontunk a vizsgálatba, amelyeket általában fontos társadalmi státusváltozónak tartanak, de amelyek Kulcsár elemzésében - részben bizonyára ideológiai okokból, részben mert ezekre nézve megbízható adatot aligha lehetett volna szerezni - nem jelentek meg. Ezek a jövedelmi és vagyoni helyzet. ${ }^{32}$ A 10. táblázat valamennyi, a vizsgálatba bevont magyarázó változónak a jogismeret adataival való lineáris összefüggését mutatja be a korrelációs adatok alapján, az egyes jogismeret-változók kapcsán előbb a korreláció erősségét és irányát jelző, Pearson-féle $\mathrm{R}$ értéket, majd a szignifikancia mértékét közölve. ${ }^{33}$

A táblázat jól mutatja, hogy legalábbis a lineáris összefüggés szorosságát tekintve messze a legmeghatározóbb az iskolai végzettség és a jogrendszerrel való kapcsolatba kerülés három változóból (olvasott-e törvényt, kért-e jogásztól tanácsot, vett-e részt tárgyaláson) képzett indexe. Azt is látjuk, hogy a jövedelmi és vagyoni helyzet is szoros kapcsolatot mutat az általános jogismerettel, akárcsak a - korábban bemutatott, szórakoztatás-tájékoztatás alapján súlyozott mutatóval mért - médiafogyasztás. A fentieken túl még az elsősorban civil-szervezeti tagsággal mért „tár-

32 Megjegyezzük, ezekre vonatkozóan ma sem lehet megbízható, sőt gyakran semmiféle adatot szerezni, noha az adatok szórása időközben nyilván jelentősen megnőtt. A jövedelem nagyságára vonatkozó kérdőívi kérdésre a többség (57\%) nem adott választ. Ugyanakkor kimarad ebből a vizsgálatból a politikai és jogi ismeretek összefüggésének vizsgálata, mivel az logikailag nem lehetséges ebben a keretben (tekintve, hogy a politikai ismeret mérőeszközét a négy alkotmányjog-ismereti változóból képeztük).

33 Ezeket az elemzéseket a 2013-as teljes, vagyis nem korrigált mintán végeztük, mivel az 1965-ös adatokkal való közvetlen összevetés itt nem lehetséges. 
sadalmi aktivitás" és az életkor mutat, némi jóindulattal, szignifikánsnak tekinthető összefüggést a teljes jogismerettel. Több olyan tényező (nem, kor, településtípus), amely Kulcsár elemzésében még határozott összefüggést mutatott a jogismerettel, napjainkban láthatóan kevésbé tünik fontosnak.

Jól látható az eltérés az egyes jogismereti indexek tekintetében is. Az államjogi ismeretek a legtöbb esetben nem mutatnak összefüggést a magyarázó változókkal (bizonyára a többször említett alacsony szórásuk miatt), míg az eljárásjogi ismeretek mutatója a legtöbb magyarázó változóval érzékelhető összefüggést mutat. A polgári jogi ismeretek mindössze két, ráadásul sajátosan „viselkedő” kérdésből álló változója pedig valahol a kettő között helyezkedik el.

Ezek az adatok jelentős mértékben egybevágnak korábbi, részletesebb és más módszerekkel (ANOVA, khi-négyzet) végzett elemzéseinkkel.

\section{0. táblázat}

A jogismeret mutatóit esetlegesen befolyásoló változók korrelációs együtthatói és szignifikanciaértékei (az összefüggés mértéke szerint csökkenő sorrendben)

\begin{tabular}{|l|c|c|c|c|c|c|c|c|}
\hline & \multicolumn{2}{|c|}{$\begin{array}{c}\text { Teljes } \\
\text { jogismeret } \\
\text { R Szf. }\end{array}$} & \multicolumn{2}{c|}{$\begin{array}{c}\text { Államjogi } \\
\text { ismeretek } \\
\text { R Szf. }\end{array}$} & \multicolumn{2}{c|}{$\begin{array}{c}\text { Eljárásjogi } \\
\text { ismeretek } \\
\text { R Szf. }\end{array}$} & \multicolumn{2}{c|}{$\begin{array}{c}\text { Polgári jogi } \\
\text { ismeretek } \\
\text { R Szf. }\end{array}$} \\
\hline Iskolai végzettség &, 279 &, 000 &, 099 &, 002 &, 293 &, 000 &, 091 &, 004 \\
\hline Jogi tapasztalat - index &, 274 &, 000 &, 097 &, 002 &, 266 &, 000 &, 119 &, 000 \\
\hline Társadalmi réteg &, 199 &, 000 &, 010 &, 774 &, 236 &, 000 &, 090 &, 007 \\
\hline Jövedelem &, 156 &, 001 &, 027 &, 584 &, 160 &, 001 &, 130 &, 007 \\
\hline Média (tájékoztató) &, 134 &, 000 &,- 003 &, 928 &, 146 &, 000 &, 125 &, 001 \\
\hline Vagyon &, 100 &, 005 &, 061 &, 090 &, 081 &, 024 &, 039 &, 273 \\
\hline Szervezeti részvétel &, 076 &, 016 &,- 002 &, 956 &, 084 &, 008 &, 066 &, 037 \\
\hline Életkor &,- 074 &, 019 &,- 025 &, 434 &,- 093 &, 003 &, 013 &, 688 \\
\hline Falusi lakos ${ }^{34}$ &,- 054 &, 088 &, 107 &, 001 &,- 072 &, 022 &,- 194 &, 001 \\
\hline Neme &,- 049 &, 119 &,- 007 &, 835 &,- 049 &, 124 &,- 053 &, 095 \\
\hline Városi lakos &, 010 &, 741 &,- 084 &, 008 &, 069 &, 030 &,- 026 &, 418 \\
\hline
\end{tabular}

A regressziós elemzés a „páronkénti” korrelációkhoz képest két szempontból jelent továbblépést. Egyfelöl lehetővé teszi, hogy megvizsgáljuk: az összes magyarázó változó ismeretében mennyire pontosan tudnánk megbecsülni a jogismeret változó értékét. Másként fogalmazva, az összes magyarázó változó hatását egyszerre vegyük figyelembe a jogismerettel kapcsolatban. Másfelöl ez azt is jelenti, hogy a multikollinealitás hatását ${ }^{35}$ ki tudjuk szürni. Vagyis az egyes változóknak önmagukban vett hatását tudjuk értelmezni.

Számos itt nem részletezendő technikai szempontot vettünk figyelembe, aminek következtében a háromértékű változókat kétértékűvé alakítottuk. Ezt tettük már ko-

\footnotetext{
34 A lineáris módszer logikája miatt külön vettük a falusi és a városi lakosság tényét (a másik két kategóriával szembeállítva).

35 Lásd az első rész módszertani bevezetőjét, illetve annak 27. lábjegyzetét.
} 
rábban a településtípus esetében, illetve a regressziós modellhez szellemi-fizikai kategóriákat képeztünk (a kisszámú mezőgazdasági fizikait az utóbbi kategóriába véve). A korváltozót is átalakítottuk, valamint a jövedelemváltozónak egy olyan kategoriális verzióját használtuk, amelyre a legtöbben, közel kétharmadnyian válaszoltak.

Mivel a regressziószámítás egyszerre sok változóval dolgozik, az egyes változók adatveszteségei összeadódnak. Mint jeleztük, ez különösen a jövedelem és kisebb mértékben a vagyoni helyzet esetében probléma. $E$ két változó együttes szerepeltetése a modellben odavezet, hogy adataink közel kétharmada elvész. Végül a vagyonihelyzet-változót kiemeltük a modellböl, ami a modell magyarázó értékét nem csökkentette. Az említett jövedelemkategória-változót alkalmazva az ezerfős mintából 422 fö került be a modellbe. Az így kialakított regressziós „ENTER” típusú modell $R^{2}$ értéke $0,135(R=0,368)$, ami ugyan nem kifejezetten magas, de már elfogadhatónak mondható. Erre utal az a tény is, hogy a kapcsolódó szignifikanciaérték egy ezrelék alatt van. A modell legfontosabb jellemzőit a 11. táblázat foglalja össze.

\section{1. táblázat}

Az ENTER regressziós modell legfontosabb adatai $\left(R^{2} 0,135\right)$

\begin{tabular}{|c|c|c|c|c|c|}
\hline \multirow{3}{*}{$\begin{array}{l}\text { Magyarázó változók } \\
\text { (a szövegben tárgyalt } \\
\text { sorrend szerint) }\end{array}$} & \multirow{2}{*}{$\begin{array}{l}\text { Béta- } \\
\text { érték }\end{array}$} & \multirow{2}{*}{ Szf. } & \multicolumn{2}{|c|}{ Korrelációs együtthatók } & \multirow[b]{2}{*}{ VIF } \\
\hline & & & „Normál” & Parciális & \\
\hline & & ,000 & & & \\
\hline Nem &,- 092 & ,067 &,- 088 &,- 090 & 1,188 \\
\hline Kor (Centrálva) &,- 055 & ,270 &,- 134 &,- 054 & 1,178 \\
\hline Iskolai végzettség (5/7 kategória) & ,245 & ,000 & ,328 & ,186 & 1,939 \\
\hline Társadalmi réteg (szellemi-fizikai) & 058 & ,306 & ,213 & ,050 & 1,510 \\
\hline Falusi lakos & 021 & ,744 &,- 035 & 016 & 1,901 \\
\hline Városi lakos &,- 010 & ,868 & ,004 &,- 008 & 1,862 \\
\hline Média (tájékoztató) & 023 & ,662 & ,138 & 022 & 1,264 \\
\hline Szervezeti részvétel & 014 & ,777 & 107 & 014 & 1,201 \\
\hline Jogi tapasztalatindikátor & 099 & 049 & ,204 & 097 & 1,203 \\
\hline Jövedelem (Z score) & ,018 & ,734 & 167 & ,017 & 1,340 \\
\hline
\end{tabular}

A szignifikanciaértékekre tekintve egyedül az iskolai végzettség esetében találunk egyértelmü összefüggést a teljes jogismerettel. Figyelembe vehető még a jogi tapasztalat, bár a szociológiai kutatásokban minimálisan elvárt 0,05-ös értékhez közel áll, miközben - meglepő módon - azt alig haladja meg a „nem” változó, amelynek negatív $R$ értéke a nők magasabb jogismeretszintjére utal. Az adatok mögött a többször említett multikollinearitás áll. Ezt jól érzékelteti a „normál” és parciális korreláció gyakran radikálisan eltérö értéke. Elöbbi azt mutatja, hogy milyen közvetlen összefüggés van az adott változó és a jogismeret között. Utóbbi azt, amikor más tényezők hatását kiszürjük. Látható például, hogy a korábbi eredményeink szerint erős összefüggés van a társadalmi réteg és a jogismeret között, más változók (így bizonyára az iskolai végzettség) hatásának kiszürése után a negyedére, a média esetében 
hatodára zsugorodik. Az első oszlopban szereplő béta-érték azt adja meg, hogy az adott változó értékeiben egyet előrelépve, hogyan változik a jogismeret mértéke. ${ }^{36}$ A VIF érték szerepe technikai. Az a tény, hogy értéke egy esetben sem haladja meg a 2,0-t, jelzi, hogy a modell elfogadható.

Ugyanezt a modellt külön-külön is vizsgáltuk a három jogterület jogismereti indikátorára, ám ennek adatait itt nem tudjuk bemutatni. A 12. táblázat összegzi a modellek magyarázó erejét és jellegzetességeit.

\section{2. táblázat}

Az egyes jogismereti indexeket magyarázó regressziós modellek sajátságai

\begin{tabular}{|l|c|l|}
\hline \multicolumn{1}{|c|}{ Jogterület } & $\mathbf{R}^{2}$ & \multicolumn{1}{c|}{ Sajátságok } \\
\hline Államjog &, 047 & $\begin{array}{l}\text { Nagyon gyenge magyarázó erő. Kizárólag az iskolai végzettség- } \\
\text { nek van szerepe. Minden más tényező szignifikanciaszintje 0,1 } \\
\text { felett van, a legtöbbé 0,5 felett. }\end{array}$ \\
\hline Eljárásjog &, 155 & $\begin{array}{l}\text { Nagyon erős magyarázó erejü modell, amelyben az iskolai vég- } \\
\text { zettség mellett a társadalmi réteg (szf. 0,014), a jövedelem (0,036) } \\
\text { és talán még a nem }(0,059) \text { is önálló magyarázó erővel bír. }\end{array}$ \\
\hline Polgári jog &, 041 & $\begin{array}{l}\text { Nagyon gyenge magyarázó erő, ahol az iskolai végzettség ha- } \\
\text { tása nem mutatható ki (szf. 0,58 !), helyette a médiafogyasztás } \\
(0,027) \text { és talán a falusi „lakosság” }(0,055) \text { mutat összefüggést, } \\
\text { utóbbi negatívat. }\end{array}$ \\
\hline
\end{tabular}

Ugyanezeknek a változóknak a hatását ún. FORWARD regressziós modellel is elemeztük. Ennek során elsőként a legerősebb magyarázó erejű változót tesszük a modellbe, majd az azt követőt és így tovább. Az iskolai végzettség egyedül magyarázza a jogismeret szórásának jelentős részét $\left(R^{2}=0,108\right)$, ezt 0,012 -del növeli a „jogi tapasztalat”, 0,009-del a „nem”, majd 0,003-0,003-del a „társadalmi réteg” és a „kor” adat hozzáadása, amivel a modell magyarázó ereje $R^{2}=0,134$ értékre nő. Az összes többi változó hozzáadása lényegében nem változtat a modell magyarázó erején; másként fogalmazva: a többi tényező nem mutat összefüggést a jogismerettel. Ez a vizsgálódás így dinamikájában megerősítette a korábbi elemzés „statikus” eredményeit. A modell végeredményét mutatja a 13. táblázat.

\section{3. táblázat}

A változók hozzáadott magyarázó értéke FORWARD regressziós modellben

\begin{tabular}{|c|l|c|c|}
\hline Modell & \multicolumn{1}{|c|}{ Hozzáadott változó } & R & R Square \\
\hline $\mathbf{1}$ & Iskolai végzettség (6/7 kategória) &, 328 &, 108 \\
\hline $\mathbf{2}$ & Jogi tapasztalatindikátor &, 346 &, 120 \\
\hline $\mathbf{3}$ & Nem &, 359 &, 129 \\
\hline $\mathbf{4}$ & Társadalmi réteg (szellemi-fizikai) &, 362 &, 131 \\
\hline
\end{tabular}

36 A nem esetében ez a férfi és nő jogismerete közötti különbség, a kor esetében egy év, az iskolai kategóriáknál pedig egy kategória (a 2013-ban mért 5 kategóriával). 


\begin{tabular}{|c|l|c|c|}
\hline Modell & \multicolumn{1}{|c|}{ Hozzáadott változó } & R & R Square \\
\hline $\mathbf{5}$ & Kor (Centrálva) &, 366 &, 134 \\
\hline $\mathbf{6}$ & Falusi lakos &, 366 &, 134 \\
\hline $\mathbf{7}$ & Média (tájékoztató) &, 367 &, 135 \\
\hline $\mathbf{8}$ & Jövedelem (Z score) &, 368 &, 135 \\
\hline $\mathbf{9}$ & Szervezeti részvétel &, 368 &, 135 \\
\hline $\mathbf{1 0}$ & Városi lakos &, 368 &, 135 \\
\hline
\end{tabular}

A táblázatból jól látható, hogy a korábbiakhoz nagyon hasonló eredményre jutunk a modellépítés dinamikájában. Egyértelmüen meghatározó az iskolai végzettség szerepe. Ehhez, és ettől függetlenül némi magyarázó erőt ad a jogrendszerrel kapcsolatban szerzett ismeretek indexe, és még egy keveset a nem, a társadalmi réteg és a kor adat. Az összes többi változó, beleértve a társadalmi aktivitást vagy a médiafogyasztást, lényegében semmit nem adnak hozzá a modell magyarázó erejéhez.

A regressziós modellek hozzásegítettek a jogismeretre ható tényezők jobb megismeréséhez napjainkban. Világossá vált, hogy a számos szóba jöhető tényező, amelyek közül több első pillantásra, akár az empirikus adatok alapján is meghatározónak tủnhet, valójában lényegtelen. Igazán meghatározó szerepe az iskolázottság szintjének van és jóval kisebb mértékben a jogrendszerrel kapcsolatban szerzett tapasztalatnak, valamint - meglepö módon - a nemnek.

Sajnos Kulcsár vizsgálata semmiféle olyan tartalommal nem bír, amely e modellhez kapcsolható lenne. ${ }^{37}$ Ám heurisztikusan mégis azt valószínüsíthetjük, illetve társadalomtudományi ismereteink is azt sugallják, hogy Kulcsár vizsgálataiban is a látszólagos összefüggések mögött gyakran hasonló rejtett összefüggések vannak, hiszen az iskolai végzettség nyilván akkor is szorosan együtt mozgott a társadalmi státusszal, a nemmel és a korral, valamint közvetlenül, illetve a koron keresztül a lakóhellyel is. Alighanem fennáll ez a fajta multikollinearitás a napilapok olvasása, kisebb mértékben a szervezeti tagság és a jogi tapasztalat esetében is. A Kulcsár vizsgálódásában és végeredményében is kulcsszerepet játszó társadalmiréteg-változónak meglehetösen kis szerepe van modellünkben, és kérdéses, hogy e módszereket alkalmazva, hogyan viselkedett volna e tényező 1965-ben. Ugyanakkor a jogi tapasztalatnak, és különösen a szervezeti tagságnak - akkori sajátos tartalma miatt (szakszervezeti, párt és tanácsi vezető pozíció) - valószínüsíthetően a mainál határozottan jelentősebb önálló hatása lehetett. Talán így áll össze, az adatok egyszerü összevetésén túl, egy annál bonyolultabb, számszerüen bizonytalanabb, ám mégis reálisabb történeti összevetés képe.

${ }^{37}$ Éppen az iskolai végzettség hatását tárgyalta Kulcsár a legkisebb mértékben. A föszövegben az öt változó közül épp csak ebben a bontásban nem jelennek meg a jogismereti adatok, és a számos, olykor három magyarázó változó együttes hatását bemutató táblázatok között is csak egyszer jelenik meg az iskolai végzettség a nemmel együtt. 


\section{Az összegzés összegzése}

Nem könnyủ az elöbbi, terjedelmes és összetett kutatás eredményeinek lényegét megragadni. Talán két tényező érdemel kiemelést: az első összességében a történelmi változásokra, a második annak okaira utal. Az adatokból egyértelmü, hogy a jogismeret általános szintje jelentős mértékben, összességében talán mintegy harmadával is nőtt az elmúlt fél évszázadban, ám e mögött a döntő tényező a lakosság iskolai végzettségi szintjének általános növekedése. A pozitív változás mögött döntő mértékben a közoktatás elmúlt közel fél évszázados fejlödésének hatása áll. Valójában a növekedés kizárólag az államjogi ismeretek esetében teljesen egyértelmü; ott valószínüsíthető, hogy minden bizonnyal a rendszerváltás társadalmi-politikai hatásai jelennek meg e tény mögött.

Elemzésünk jelentős részben arra is irányult, hogy mi határozza, illetve határozta meg a jogismeret szintjét, és e tekintetben érzékelhetünk-e változásokat? Az elemzés lehetőségei jobbára csak a 2013-as adatok esetében voltak adottak. Napjainkban az iskolai végzettség szerepe domináns, és minden más tényező látszólagos hatása mögött is elsősorban e tényező sejlik fel. Nem tudhatjuk, hogy ugyanez az elemzés mit mutatott volna az 1965-ös adatok esetében, de valószínüsítjük, hogy a Kulcsár elemzésében kialakuló kép jelentősen más üzenetet hordozna.

Összegezve: Kulcsár 1965-ös kutatása lehetővé tette, hogy megbízható matematikai-statisztikai módszerek segítségével képet alkothassunk a magyar lakosság jogismeretének fél évszázados dinamikáiról. E ponton már megfogalmazhatunk különféle konklúziókat, de azt mindenképpen figyelembe kell venni, hogy a jogismeret problematikája a jogtudat tágabb kérdéskörébe illeszkedik, így ezek az eredmények csak széles körü jogtudatkutatások keretében értelmezhetőek teljességükben.

\section{Abstract}

The paper deals with the level of legal knowledge among the Hungarian population measured with a representative survey asking questions regarding the knowledge of certain constitutional, civil, administrative and procedural legal rules relevant in everyday life. Our findings are compared to a research carried out in 1965, using the same questions. Furthermore we analysed the relationship of knowledge level as a dependent variable with (i) socio-demographic (gender, age, education, etc.), (ii) media consumption (some 30 written, electronic and internet-based items), (iii) interaction with the legal system (read a law, consulted with a lawyer, participated in a trial) and (iv) civic activity. We found that the level of education is crucial, and interaction with the legal system has some additional significant impact, too. All other independent variables seem to have less significance or no impact at all. The relative strength of explanatory variables has largely changed in the past decades and in some cases even the direction of impact altered (for example women seem to be more educated about the law nowadays, in a sharp contrast to the 1965 data.) 